\title{
Simulated European stalagmite record and its relation to a quasi-decadal climate mode
}

\author{
G. Lohmann ${ }^{1}$, A. Wackerbarth ${ }^{2}$, P. M. Langebroek ${ }^{1,4}$, M. Werner ${ }^{1}$, J. Fohlmeister ${ }^{2}$, D. Scholz ${ }^{3}$, and A. Mangini' ${ }^{2}$ \\ ${ }^{1}$ Alfred Wegener Institute for Polar and Marine Research, Bussestr. 24, 27570 Bremerhaven, Germany \\ ${ }^{2}$ Heidelberg Academy of Sciences, Im Neuenheimer Feld 229, 69120 Heidelberg, Germany \\ ${ }^{3}$ Institut für Geowissenschaften, Johannes-Gutenberg-Universität Mainz, Johann-Joachim-Becher-Weg 21, \\ 55128 Mainz, Germany \\ ${ }^{4}$ Bjerknes Centre for Climate Research, Bergen, Norway
}

Correspondence to: G. Lohmann (gerrit.lohmann@awi.de)

Received: 31 July 2012 - Published in Clim. Past Discuss.: 13 August 2012

Revised: 24 December 2012 - Accepted: 4 January 2013 - Published: 21 January 2013

\begin{abstract}
A synthetic stalagmite $\delta^{18} \mathrm{O}$ record for the Bunker Cave $\left(51^{\circ} \mathrm{N}, 7^{\circ} \mathrm{E}\right)$ is constructed using a combined climatestalagmite modelling approach where we combine an atmospheric circulation model equipped with water isotopes and a model simulating stalagmite calcite $\delta^{18} \mathrm{O}$ values. Mixing processes in the soil and karst above the cave represent a natural low-pass filter of the speleothem climate archive. Stalagmite $\delta^{18} \mathrm{O}$ values at Bunker Cave lag the regional surface climate by 3-4 yr. The power spectrum of the simulated speleothem calcite $\delta^{18} \mathrm{O}$ record has a pronounced peak at quasi-decadal time scale, which is associated with a large-scale climate variability pattern in the North Atlantic. Our modelling study suggests that stalagmite records from Bunker Cave are representative for large-scale teleconnections and can be used to obtain information about the North Atlantic and its decadal variability.
\end{abstract}

\section{Introduction}

Speleothems are a valuable archive of past climate variability since they allow precise dating (Richards and Dorale, 2003; Fairchild et al., 2006; Scholz and Hoffmann, 2008) and provide high-resolution climate proxy data (Wang et al., 2001; Dayem et al., 2010, Pausata et al., 2011a). The most commonly used climate proxies in speleothems are stable carbon and oxygen isotope signals $\left(\delta^{13} \mathrm{C}\right.$ and $\left.\delta^{18} \mathrm{O}\right)(\mathrm{McDermott}$, 2004; Yuan et al., 2004; Lachniet, 2009) as well as various trace elements such as magnesium or strontium (Fairchild and Treble, 2009). Their potential for paleoclimate research is related to the question whether they reflect local climate conditions above the cave or large-scale climate variability modes. Such modes show coherent spatial structures and were identified both in the tropical Pacific (e.g. Philander, 1990), North Pacific (Walker and Bliss, 1932), and the North Atlantic (Walker, 1924; Hurrell, 1995; Deser and Blackmon, 1993). Part of the problem of understanding climate variability is linked to the question of identifying the corresponding spatial patterns (e.g. Rimbu et al., 2001, Felis et al., 2004; Lohmann et al., 2004; Langebroek et al., 2011). A climatespeleothem proxy relationship is postulated through a correspondence between speleothem $\delta^{18} \mathrm{O}$ records and several local processes such as rainfall amount and large-scale effects (e.g. Fairchild and Treble, 2009; Drysdale et al., 2009; LeGrande and Schmidt, 2009; Lewis et al., 2010). Baker et al. (2011) analyse the climate-proxy relationship for an annually laminated Scottish stalagmite $\delta^{18} \mathrm{O}$ and found little correspondence to instrumental climate data, although a clear relationship between local rainfall $\delta^{18} \mathrm{O}$ and atmospheric circulation is observed. They concluded that this prevents a simple palaeoclimate interpretation in terms of atmospheric circulation for the stalagmite $\delta^{18} \mathrm{O}$ proxy in this region.

Here, we follow their idea and trace the simulated speleothem $\delta^{18} \mathrm{O}$, which stems from the composition of infiltrated water in a cave. We analyse the climate variability pattern related to variations in a cave system in Central Europe, which is under the influence of maritime climate. It is well known that the climate over the North Atlantic sector varies 
on quasi-decadal to multi-decadal timescales (Deser and Blackmon, 1993; Hurrell, 1995; Sutton and Allen, 1997). In this pattern, the atmospheric and oceanic circulation generate a tripole pattern in sea surface temperature (SST) anomalies (Bjerknes, 1964; Deser and Blackmon, 1993; Kushnir, 1994; Dima and Lohmann, 2004). Modelling studies with atmospheric general circulation models (AGCMs) of different complexity forced by global SST variability over the last century show that the atmospheric circulation over the North Atlantic is at least partly predictable on decadal timescales if global SST variability can be predicted (Rodwell et al., 1999; Latif et al., 2000; Robertson et al., 2000; Sutton and Hodson, 2003; Grosfeld et al., 2007; Keenlyside et al., 2008). On interannual time scales, internal variability of the atmosphere plays an important role in determining atmospheric circulation over the Atlantic sector (e.g. Mignot and Frankignoul, 2005).

However, it remains poorly understood how changing climatic boundary conditions affect the strength and dynamics of these natural oscillations in the North Atlantic realm on longer time scales. Such information can be inferred from the past using climate proxy data if the large-scale teleconnections remain unaffected (e.g. Justino and Peltier, 2005; Brachert et al., 2006; Li and Battisti, 2008; Pausata et al., 2009, 2011b).

Here we elaborate the large-scale relation of the $\delta^{18} \mathrm{O}$ signal recorded in a simulated stalagmite, for the location of Bunker Cave $\left(51^{\circ} \mathrm{N}, 7^{\circ} \mathrm{E}\right)$. The cave is located in the Rhenish Slate Mountains in the western part of Germany (Riechelmann et al., 2011; Fohlmeister et al., 2012). Our model approach is based on an AGCM including water stable isotopes (Werner and Heimann, 2002) as well as a proxy model for the general processes influencing the $\delta^{18} \mathrm{O}$ signal of cave drip water and speleothem calcite (Wackerbarth et al., 2010). This model was developed in order to better understand the influence of climate change on the $\delta^{18} \mathrm{O}$ values of speleothem calcite. We examine the related large-scale variability on interannual to multi-decadal timescales in the North Atlantic realm. In addition, our approach helps to study the relationship between climate change and the recorded speleothem proxy signals.

\section{Methods}

\subsection{Atmospheric model}

The applied model was the Hamburg AGCM ECHAM4 (Roeckner et al., 1996) with both water stable isotopes $\mathrm{H}_{2}^{18} \mathrm{O}$ and HDO explicitly cycled through the water cycle of the model (Werner and Heimann, 2002). The simulation was performed in T30 resolution ( 3.75 by 3.75 spatial grid; 19 vertical levels). Observed monthly values of the global sea ice and sea surface temperature data set (GISST2.2) of the UK Meteorological Office were prescribed for the period 1908-1994
(Rayner et al., 1996). Atmospheric concentrations of greenhouse gases $\left(\mathrm{CO}_{2}, \mathrm{CH}_{4}, \mathrm{~N}_{2} \mathrm{O}\right)$ but no additional aerosol forcing were also prescribed according to the observations. With the same SST data and the same model, ensemble integration with three members was performed in order to study interannual to multi-decadal variability (Latif et al., 2000; Grosfeld et al., 2007). Furthermore, our water isotope module has been applied for recent and past interglacial variability (Werner and Heimann, 2002; Herold and Lohmann, 2009; Cruz et al., 2009).

From the model run, we extract the local climate and oxygen isotope signature for the region $7.5-8.5^{\circ} \mathrm{E}, 51-52^{\circ} \mathrm{N}$. This information is then used as the input for the stalagmite model (Wackerbarth et al., 2010, 2012).

\subsection{Stalagmite model}

Cave drip water inherits the $\delta^{18} \mathrm{O}$ value from the meteoric precipitation above the cave, but is modified in the soil-karst system before it enters the cave and feeds the stalagmite. The Oxygen isotope Drip water and Stalagmite Model (ODSM) (Wackerbarth et al., 2010) simulates this modification of the $\delta^{18} \mathrm{O}$ value from meteoric precipitation $\left(\delta^{18} \mathrm{O}_{\text {precip }}\right)$ to calcite precipitation on the stalagmite surface.

The first process modifying the $\delta^{18} \mathrm{O}$ value is evapotranspiration. Evaporation increases the $\delta^{18} \mathrm{O}$ value of the water due to the preferential removal of lighter isotopes. The remaining amount of water represents the contribution to the drip water. During warmer months, most of the water is lost during evapotranspiration. During the colder season, this effect is largely reduced. In the ODSM, the amount of evapotranspiration is determined by ECHAM4 and the effect on the $\delta^{18} \mathrm{O}$ value calculated by Majoube (1971).

Due to the higher $p \mathrm{CO}_{2}$ in the soil air compared to the atmosphere, the infiltrating water forms carbonic acid and dissolves the host rock. This process does not affect the $\delta^{18} \mathrm{O}$ value of the water. The extent of mixing of water in the soil, which can range from days to decades depending on the individual cave system, may have a large effect on the $\delta^{18} \mathrm{O}$ value of the water. The mixing smoothes the seasonal variability of the $\delta^{18} \mathrm{O}_{\text {precip }}$ values, and the drip water $\delta^{18} \mathrm{O}$ value shows a largely reduced variability around the infiltration-weighted mean $\delta^{18} \mathrm{O}_{\text {precip value. }}$

When the drip water enters the cave, $\mathrm{CO}_{2}$ degasses, and calcite precipitates and forms a stalagmite (Kaufmann, 2003; Mühlinghaus et al., 2007; Dreybrodt and Scholz, 2011). In the ODSM, the isotope fractionation between the $\delta^{18} \mathrm{O}$ value of the drip water $\left(\delta^{18} \mathrm{O}_{\text {drip }}\right)$ and the precipitated speleothem calcite $\left(\delta^{18} \mathrm{O}_{\text {calc }}\right)$ is calculated as described by the models of Scholz et al. (2009), Mühlinghaus et al. (2009) and Deininger et al. (2012) with dependence on cave temperature, drip interval and supersaturation with respect to calcite. For a detailed description, see Wackerbarth et al. $(2010,2012)$ and Wackerbarth (2012). 

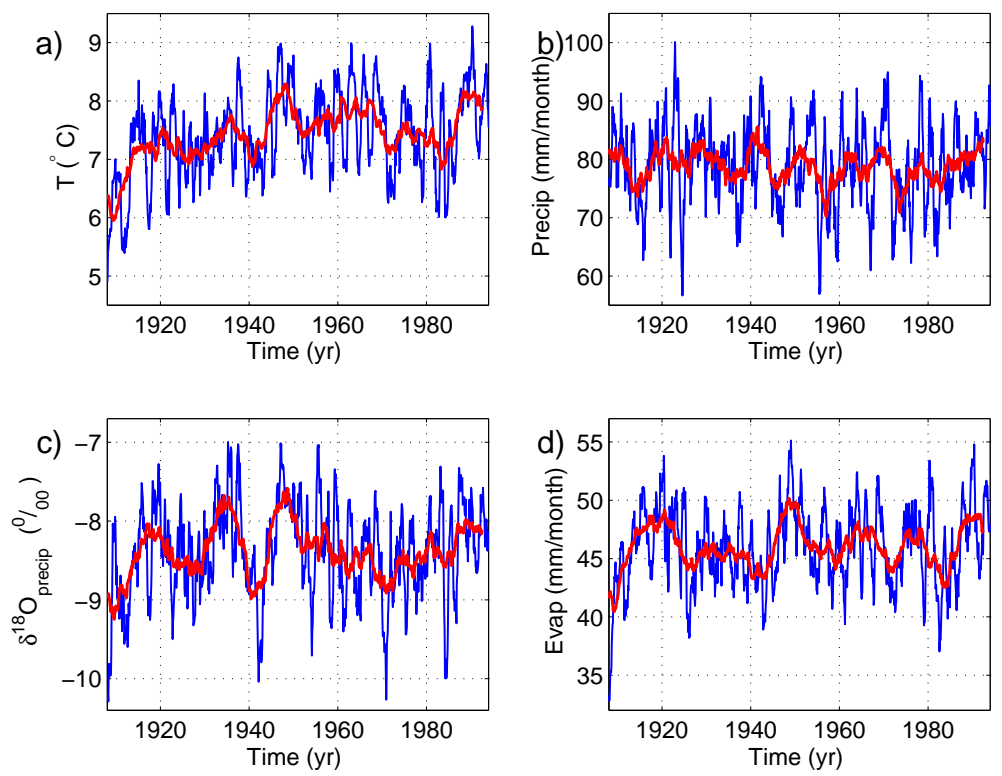

Fig. 1. Local input time series at the cave site: (a) surface temperature, (b) precipitation, (c) $\delta^{18} \mathrm{O}_{\text {precip }}$, (d) evaporation values at Bunker Cave. Blue lines indicate the 12-month and red lines the 60-month running mean values, respectively.

For the application in this study, the ODSM is used as a forward model, which is forced by output parameters from ECHAM4 (temperature, precipitation, evaporation, $\delta^{18} \mathrm{O}_{\text {precip }}$ ) in monthly resolution in order to capture the seasonality. Cave- and drip site-specific parameters were appropriately adjusted for Bunker Cave based on a long-term monitoring program (Riechelmann et al., 2011). The mixing time of water parcels in the soil and karst is assumed to be 48 months (Wackerbarth, 2012), the mean value of the drip interval $3600 \mathrm{~s}$, and the mixing parameter set to 1 (the latter two parameters are needed for calculating kinetic isotope fractionation; see Mühlinghaus et al., 2009 and Deininger et al., 2012 for details). The extent of mixing of water parcels in the aquifer only affects the degree of smoothing of the $\delta^{18} \mathrm{O}$ value of the drip water. The mean $\delta^{18} \mathrm{O}$ value of the water remains unchanged.

We note that the simulated stalagmite $\delta^{18} \mathrm{O}$ values are given in monthly resolution and, therefore, show a higher variability than the values expected for natural stalagmites from Bunker Cave. Due to their relatively low growth rate, these normally have a temporal resolution of about 8-10 yr (Fohlmeister et al., 2012).

\section{Results}

We start with local temperature and the hydrological cycle in the AGCM, indicating pronounced interannual and decadal climate variability (Fig. 1). The simulated surface temperature, local precipitation, evaporation, and $\delta^{18} \mathrm{O}_{\text {precip }}$ at the cave site serve as the main input parameters determining the cave temperature, soil humidity and speleothem $\delta^{18} \mathrm{O}_{\text {calc }}$.
The simulated monthly local $\delta^{18} \mathrm{O}_{\text {precip }}$ values and surface temperature indicate a positive correlation with a smaller slope for higher temperatures (Fig. 2).

The ODSM stalagmite proxy model calculates the cave temperature (Fig. 3a) from the running mean over the past 12 months of the surface temperature and simulates the expected speleothem $\delta^{18} \mathrm{O}_{\text {calc }}$ values at Bunker Cave (Fig. 3b). To examine the behaviour of the simulated proxy, we analyse the spectra for the input and output of the speleothem calcite. The local temperature and $\delta^{18} \mathrm{O}_{\text {precip }}$ indicate pronounced interannual variability, whereas $\delta^{18} \mathrm{O}_{\text {drip }}$ and $\delta^{18} \mathrm{O}_{\text {calc }}$ exhibit pronounced decadal variability (Figs. 3 and 4 ). The spectra of the temperature, speleothem $\delta^{18} \mathrm{O}_{\text {calc }}$ as well as the local $\delta^{18} \mathrm{O}_{\text {precip }}$ values show interannual (with peaks at about 3 and $5 \mathrm{yr}$ ) and quasi-decadal variability (at about $14 \mathrm{yr}$ ). The decadal peak is not significant for temperature and $\delta^{18} \mathrm{O}_{\text {precip }}$ (Fig. 4a and c), in contrast to $\delta^{18} \mathrm{O}_{\text {drip }}$ and $\delta^{18} \mathrm{O}_{\text {calc }}$ where the interannual variability in $\delta^{18} \mathrm{O}_{\text {drip }}, \delta^{18} \mathrm{O}_{\text {calc }}$ is suppressed (Fig. 4b and d) and the power spectra emphasise pronounced peaks at about $14 \mathrm{yr}$. The variability of $\delta^{18} \mathrm{O}_{\text {precip }}$ has a flatter spectrum as compared to $\delta^{18} \mathrm{O}_{\text {drip }}, \delta^{18} \mathrm{O}_{\text {calc }}$ (Fig. 4).

In order to compare the local $\delta^{18} \mathrm{O}_{\text {precip }}$ with $\delta^{18} \mathrm{O}_{\text {calc }}$, we apply a low-pass filter of $5 \mathrm{yr}$ to local $\delta^{18} \mathrm{O}_{\text {precip. }}$. The lag correlation between these quantities shows a significant lag at about 3-5 yr (Fig. 5), which is related to the infiltration of a water parcel and its inflow into the cave. This value is consistent with earlier work at Bunker Cave (Kluge et al., 2010; Wackerbarth et al., 2010). We find that this lag is not very sensitive to the low-pass filtering when using 4,5 , or $6 \mathrm{yr}$ (not shown). 

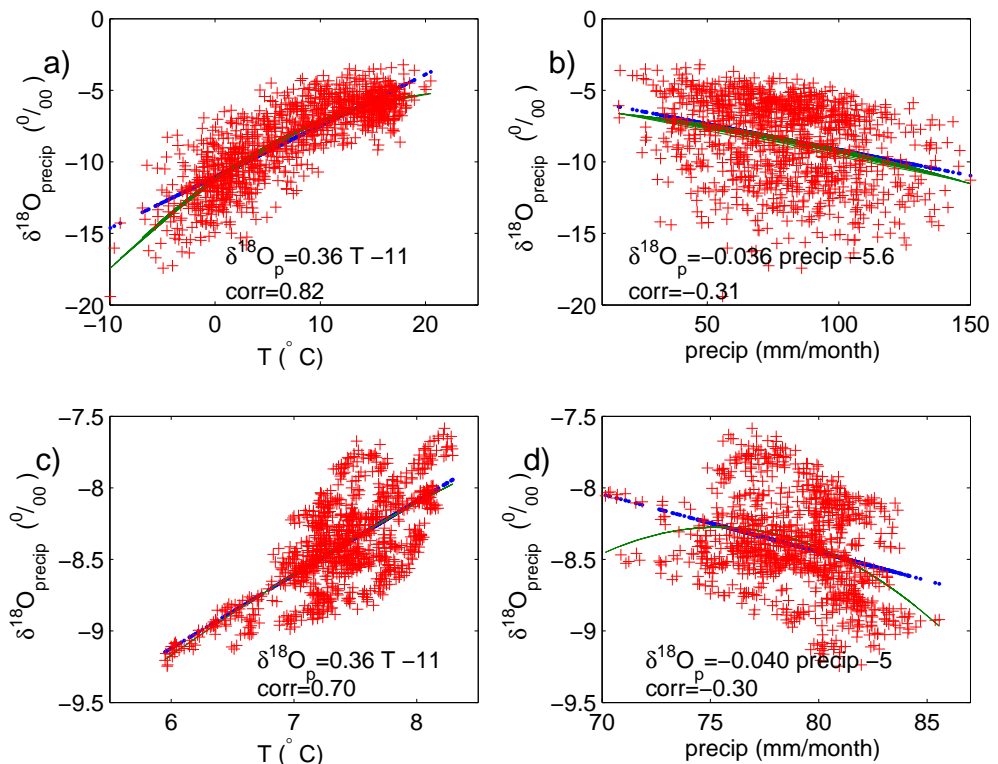

Fig. 2. Relationships between local $\delta^{18} \mathrm{O}_{\text {precip }}$ vs. surface temperature (a, c) and precipitation (b, d) at the cave site. (a) and (b) for the monthly values, and (c) and (d) for the 60-month running mean values. The linear regression lines are shown in blue; green lines indicate a second-order polynomial fit.

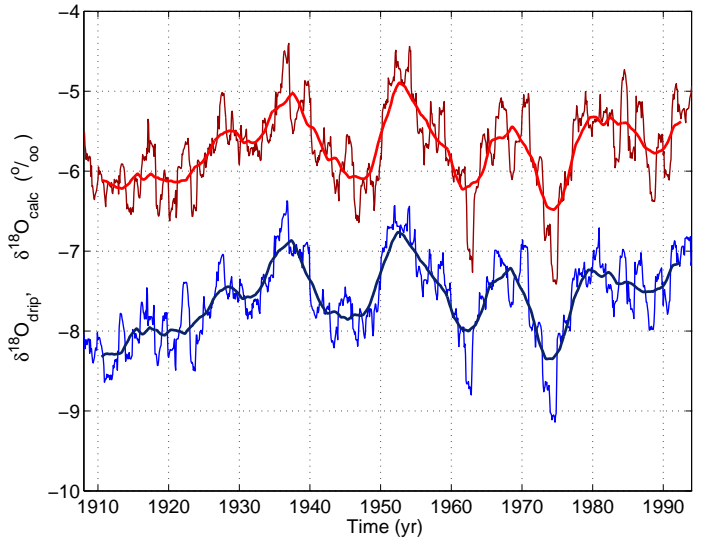

Fig. 3. Time series of the simulated monthly mean (speleothem $\delta^{18} \mathrm{O}_{\text {calc }}$ and $\delta^{18} \mathrm{O}_{\text {drip }}$ values at Bunker Cave). The thick lines show the 60-month running mean.

In order to relate the simulated $\delta^{18} \mathrm{O}_{\text {calc }}$ signal to the largescale climate pattern and to eliminate the noise in the system, we filter the SST, surface temperature, and $\delta^{18} \mathrm{O}_{\text {precip }}$ with the low-pass filter of $5 \mathrm{yr}$ in the following (Figs. 6-8). Prior to the correlations, the seasonal cycle was removed, the time series detrended, and the data normalized to their standard deviation.

The correlation of the local $\delta^{18} \mathrm{O}_{\text {precip }}$ values with SST (Fig. 6a) shows a band of positive correlation between 30 and $60^{\circ} \mathrm{N}$. Areas showing a significant correlation $(95 \%$ confidence level, t-test) are coloured. A similar correlation pattern is obtained when applying a 3-yr lag on the simulated $\delta^{18} \mathrm{O}_{\text {calc }}$ signal (Fig. 6b). The similarity in the panels of Fig. 6 is due to the time delay between the simulated $\delta^{18} \mathrm{O}_{\text {calc }}$ signal and the local $\delta^{18} \mathrm{O}_{\text {precip }}$ caused by infiltration. Similar patterns are obtained in composite map analysis (von Storch and Zwiers, 1999) between the $\delta^{18} \mathrm{O}_{\text {calc }}$ and SST (not shown). The SST maps (Fig. 6) reflect ocean advection around the Gulf Stream area south of Newfoundland further downstream, which will be discussed below.

Also of interest are the hydrological cycle and its spatial extension. Figure 7 displays the correlation map of the $\delta^{18} \mathrm{O}_{\text {precip }}$ values with respect to the local $\delta^{18} \mathrm{O}_{\text {precip }}$ values (Fig. 7a) and with respect to the 3 -yr lagged $\delta^{18} \mathrm{O}_{\text {calc }}$ (Fig. 7b), indicating a regional coherence in Central Europe and at the eastern coast of North America. The similarity of both panels in Fig. 7 (note the different colour scales) is due to the lag correlation (Fig. 5). Furthermore, part of the $\delta^{18} \mathrm{O}_{\text {precip }}$ correlation pattern in Fig. 7 bears similarities with the associated SST correlation pattern (Fig. 6).

In order to understand the coherence in the SST correlation (Fig. 6), we apply an empirical orthogonal function (EOF) analysis (von Storch and Zwiers, 1999) of observed SSTs using the updated GISST sea surface temperature data set (Rayner et al., 2006). Figure 8 shows two distinct variability patterns in the North Atlantic Ocean: the first EOF explains $38 \%$ of the variance (Fig. 8a) with pronounced decadal and multi-decadal timescale variability in the principle component (PC1) (Fig. 8c). The second EOF explains $9 \%$ of the variance and shows zonal bands of SST stacked in the meridional direction (Fig. 8b). This mode is dominant on quasi-decadal timescales (Fig. 8d). Both EOFs account for a substantial amount of North Atlantic variability, and their 

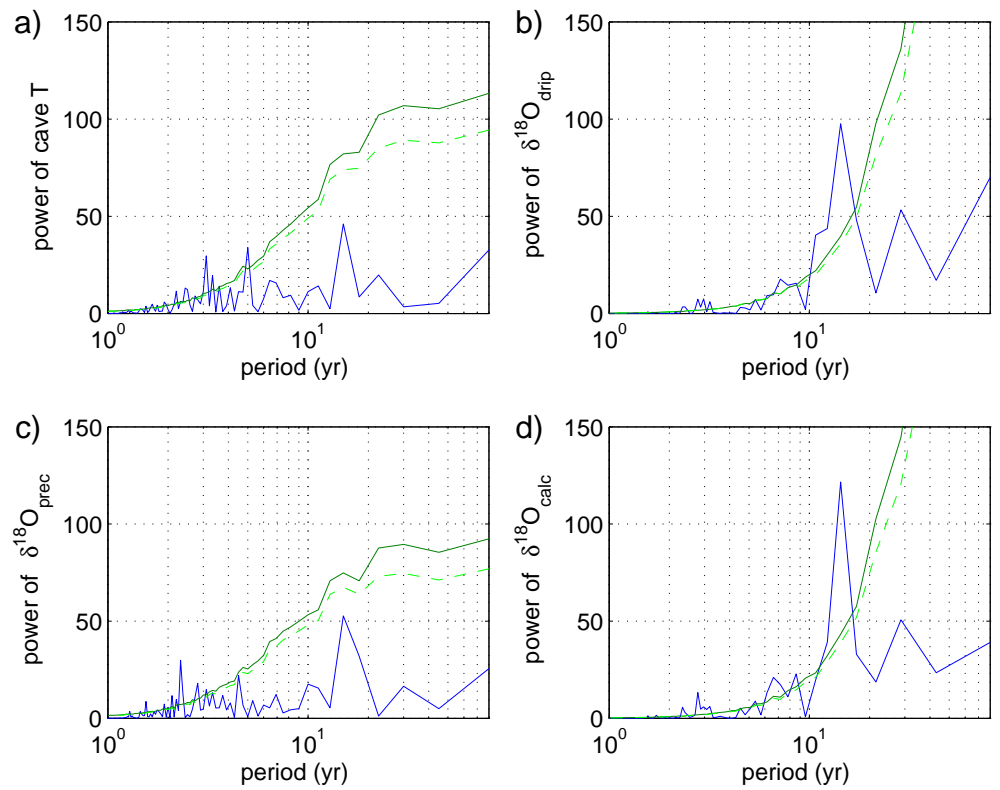

Fig. 4. Power spectra of the annual mean (a) cave temperature, (b) $\delta^{18} \mathrm{O}_{\text {drip }}$, (c) $\delta^{18} \mathrm{O}_{\text {precip }}$, (d) $\delta^{18} \mathrm{O}_{\text {calc }}$ at the Bunker Cave. The green lines denote the $95 \%$ (90\%) highest spectrum of $1000 \mathrm{AR}(1)$ processes with the same autocorrelation.

signature can be recovered in the coherent correlation fields (Figs. 6 and 7).

\section{Discussion}

Instrumental surface temperature data over the last century depict strong variability at interannual to multidecadal time scales. There is evidence that the global climate system contains modes of climatic variability operating on decadal to multidecadal time scales involving temperature and atmospheric circulation (e.g. Deser and Blackmon, 1993; Kushnir, 1994; Mann et al., 1995; Delworth and Mann, 2000; Dima and Lohmann, 2004; Liu, 2012). Here we want to elaborate the temporal behaviour of the speleothem climate archive for a specific cave site in Germany $\left(51^{\circ} \mathrm{N}, 7^{\circ} \mathrm{E}\right)$ where large-scale patterns may play a role. We combine two models: one AGCM and a speleothem proxy model for Bunker Cave. We build pseudo-proxy data by calculating the local speleothem $\delta^{18} \mathrm{O}_{\text {calc }}$ values in Bunker Cave (Fig. 3b). This allows attributing dominant signals of variability in observed and proxy data of the North Atlantic region to changes in the forcing. Because the relation of $\delta^{18} \mathrm{O}_{\text {precip }}$ with temperature is much more pronounced than for precipitation on all time scales (Fig. 2), we find a strong relation with the large-scale temperature, and only weak for precipitation (not shown). The decadal SST signature is characterized by a remote North Atlantic pattern (Fig. 6) on a quasi-decadal time scale (Fig. 4). This also projects to a European regional $\delta^{18} \mathrm{O}_{\text {precip }}$ pattern (Fig. 7a), which affects the $\delta^{18} \mathrm{O}_{\text {calc }}$ with a lag of 3-4 yr.

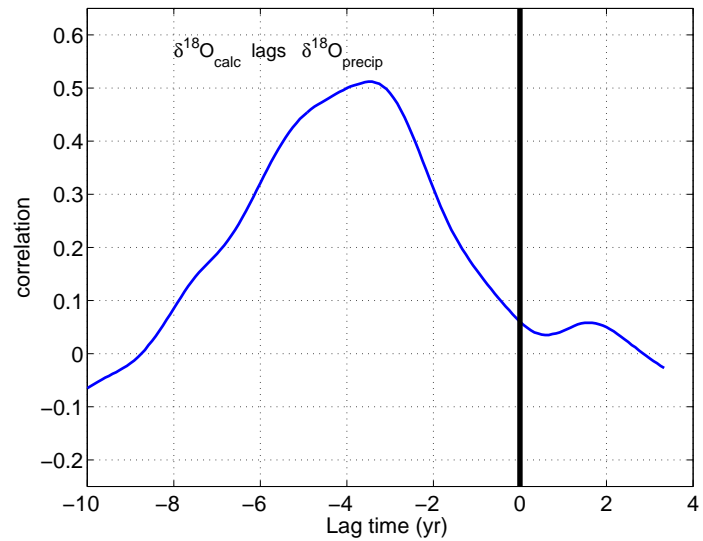

Fig. 5. Lag correlation between the 5-yr low-pass filtered $\delta^{18} \mathrm{O}_{\text {precip }}$ and $\delta^{18} \mathrm{O}_{\text {calc }}$ values. $\delta^{18} \mathrm{O}_{\text {calc }}$ lags $\delta^{18} \mathrm{O}_{\text {precip }}$ by $3-4 \mathrm{yr}$. Values above 0.41 are statistically significant taking into account the degrees of freedom (t-test).

The mode indicates the propagation of SST anomalies from the Gulf Stream region along the gyre circulation (Dima and Lohmann, 2004, cf. Fig. 5). Evidence for the Gulf Stream SST anomalies to be transferred from mid-latitudes into the tropics through surface advection is further supported by a lag correlation analysis of $\delta^{18} \mathrm{O}_{\text {precip }}$ (and $\delta^{18} \mathrm{O}_{\text {calc }}$ ) with the SST (not shown). On decadal timescales, local $\delta^{18} \mathrm{O}_{\text {precip }}$ (and $\delta^{18} \mathrm{O}_{\text {calc }}$ ) is largely determined by the surrounding SSTs. We note that a moderate correlation $(\rho=0.4)$ with temperature indicates that other processes than SST also affect the $\delta^{18} \mathrm{O}_{\text {calc }}$. Besides the effect through the modulation of 
a)
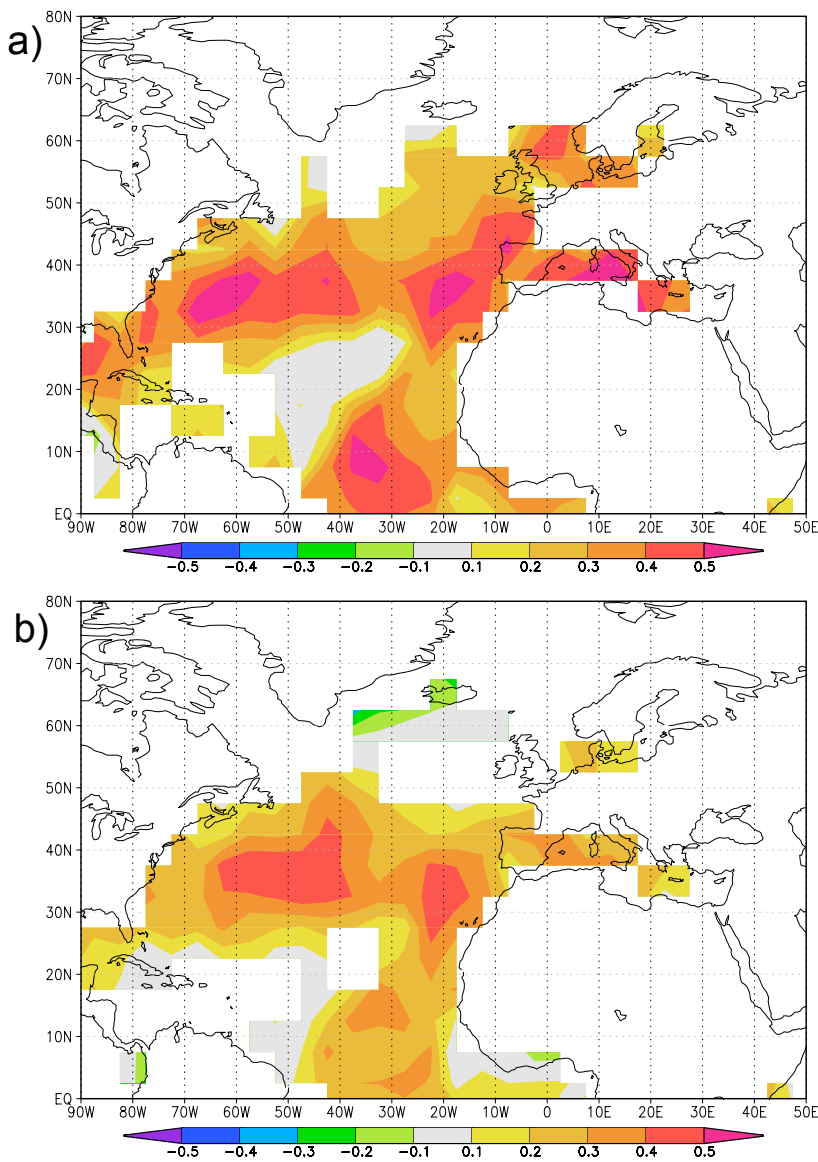

Fig. 6. (a) In-phase correlation of the simulated local $\delta^{18} \mathrm{O}_{\text {precip }}$ values and SST. (b) 3-yr lag correlation of the simulated $\delta^{18} \mathrm{O}_{\text {calc }}$ values and SST. Areas showing a significant correlation (95\% confidence level, t-test) are coloured. The data were detrended, and a 5-yr low-pass filter was applied (see text).

$\delta^{18} \mathrm{O}$ via temperature, the hydrological cycle shows a spatially coherent pattern (Fig. 7). Thus, we expect a similar temporal behaviour in the areas showing a positive correlation in Fig. 7, e.g. in eastern North America.

It has been proposed that the quasi-decadal mode results from ocean-atmosphere and tropics-midlatitudes interactions in the North Atlantic Basin (Deser and Blackmon, 1993; Dima et al., 2001; Dima and Lohmann, 2004). We run the model with random input and the same lag correlation, and found no distinct frequency peak (red noise in Fig. 4) suggesting that other than random processes are responsible for the quasi-decadal peak.

An important question is the mechanism of the filtering through the speleothem climate archive. Due to mixing processes in the aquifer, the $\delta^{18} \mathrm{O}_{\text {precip }}$ signal is smoothed to an infiltration-weighted mean $\delta^{18} \mathrm{O}$ value. The extent of mixing determines the variance of the simulated $\delta^{18} \mathrm{O}_{\text {drip }}$. We find that the spectrum of $\delta^{18} \mathrm{O}_{\text {calc }}$ in Bunker Cave is dampened for interannual time scales. We emphasize that this feature
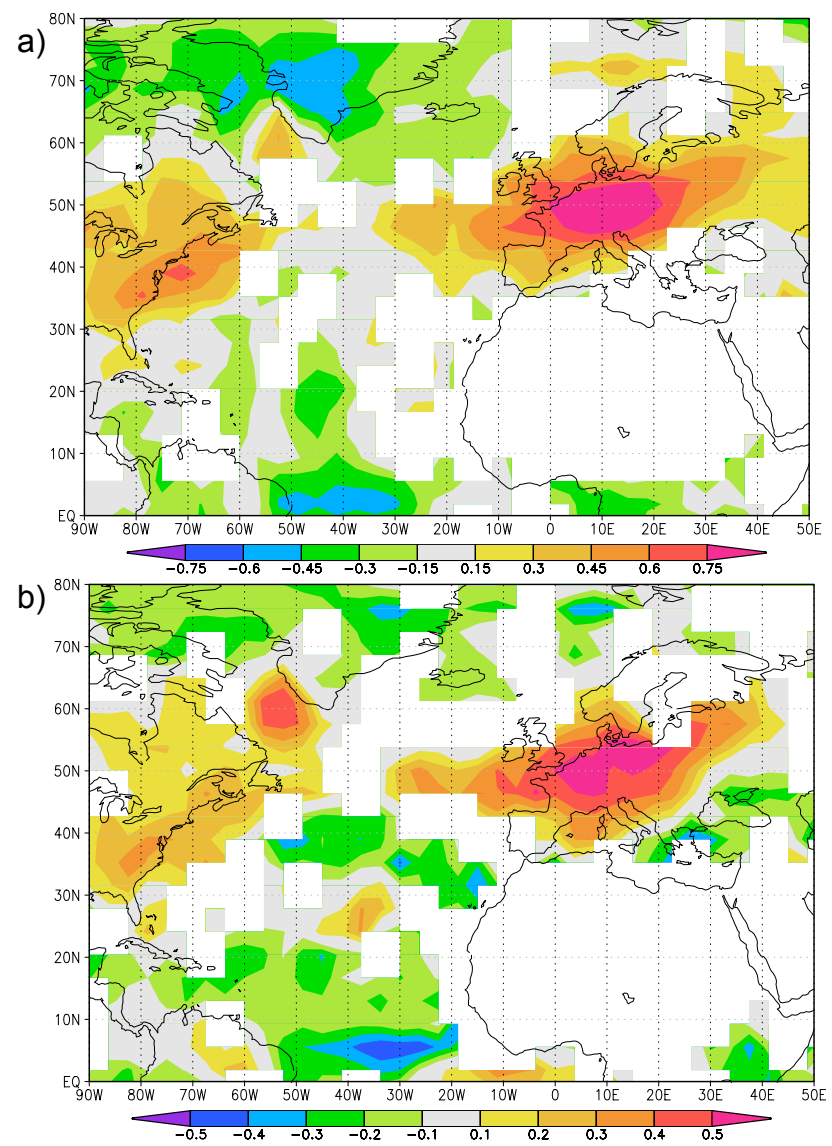

Fig. 7. As Fig. 6, but for $\delta^{18} \mathrm{O}_{\text {precip }}$ instead of the SST field.

of the recorder system is location-dependent and can be calibrated to agree with the observed natural variance in the particular cave system (Wackerbarth et al., 2010). We admit that the stalagmite model has a simplified karst hydrology (effectively an adjustable lag function), and future models may take into account more complex processes.

For paleoclimate reconstruction, a smoothing of the signal can be considered as an advantage, because it eliminates unwanted stochastic contributions. Werner and Heimann (2002) found that simulated $\delta^{18} \mathrm{O}$ records at ice core sites indicate year-to-year variations masked by internal atmospheric variability producing a low signal-to-noise ratio. Indeed, one can interpret ice core proxy data in terms of the frequency of weather patterns (Rimbu and Lohmann, 2010). If a proxy filters out the inherent noise of the climate system, it may be easier to detect a deterministic response to a large-scale SST pattern. The smoothing, of course, makes it more difficult to detect the corresponding mechanism, especially when dealing with relatively short periods (e.g. Baker et al., 2011). We admit that the actual mixing processes in real caves are more complex than in our ODSM model (Wackerbarth et al., 2010) and might be even climate dependent. 

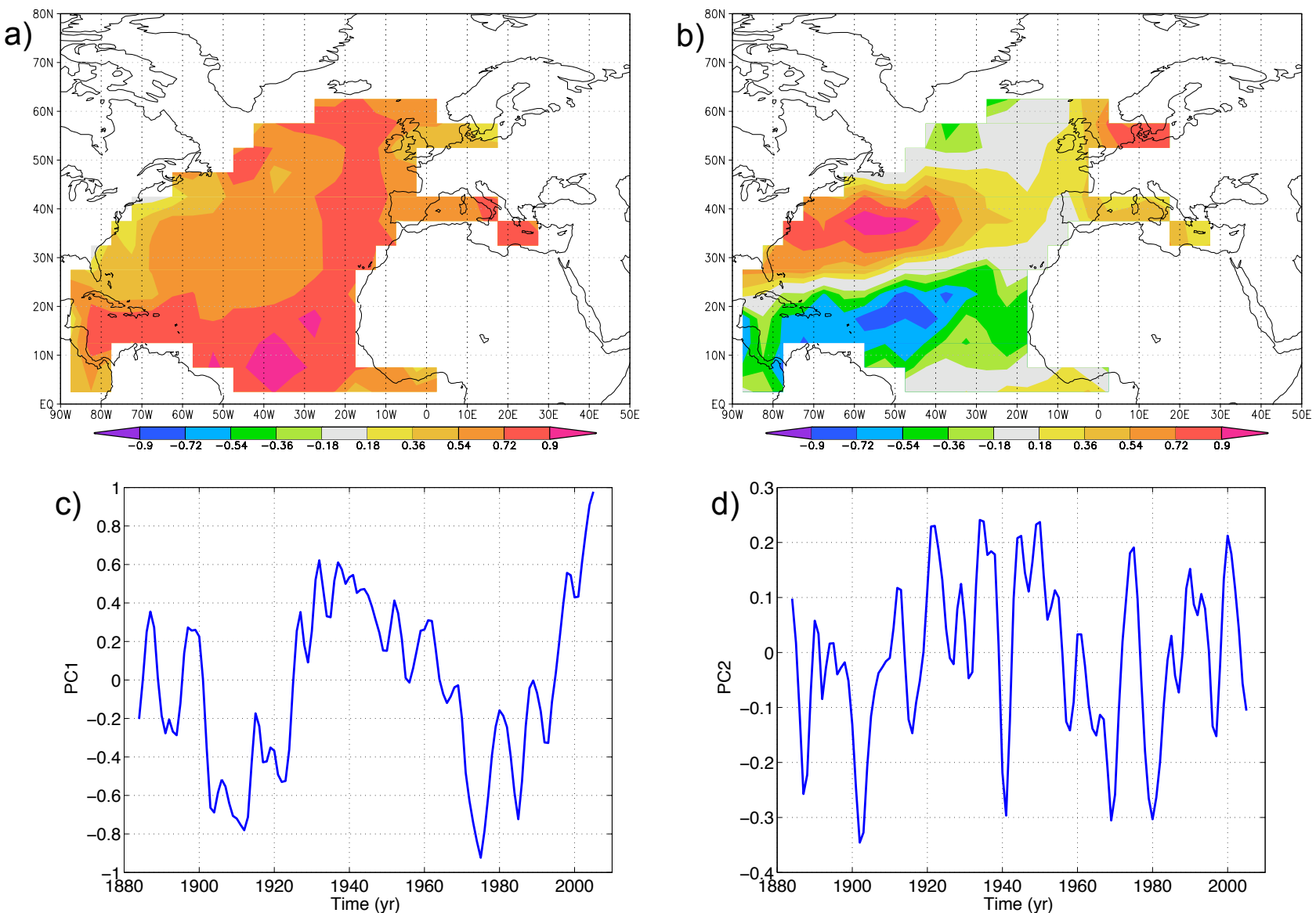

Fig. 8. North Atlantic EOFs using the updated GISST sea surface temperature data set (Rayner et al., 2006). (a) First EOF: $38 \%$ of the variance, (b) EOF2: $9 \%$ of the variance. (c) Principle component PC1, (d) PC2. The data were detrended, and a 5-yr low-pass filter was applied (see text).

\section{Conclusions}

Several attempts to reconstruct reliable climate information from stalagmite $\delta^{18} \mathrm{O}$ values over the last few centuries have been made to reconstruct large-scale climate patterns for the last millennium (see, for instance, the review papers by McDermott, 2004 and Lachniet, 2009). At present, the modes of climate variability and their modulation through longer-term background climate, and how this has varied in the past, are only known for selected sites with high-resolution proxy data (e.g. Rimbu et al., 2001; Lohmann and Schöne, 2013). Accordingly, climate models used to assess potential changes of these climate modes in the past and future are only poorly constrained.

On the other hand, cave monitoring programs do not cover decades yet, which limits their potential to study the environmental processes relevant for climate reconstructions. Using a pseudo-proxy approach extracted from AGCM simulations and a proxy module, we analyse the (modelled) reconstructions in light of variability modes. We find that the regional response in speleothem $\delta^{18} \mathrm{O}_{\text {calc }}$ is sensitive to environmental changes in terms of temperature and the hydrological cycle. We find a clear signature of the Atlantic quasi-decadal and multi-decadal variability modes (Deser and Blackmon, 1993; Dima et al., 2001; Dima and Lohmann, 2004, 2007; Liu, 2012).

Furthermore, we show that the speleothem climate archive can significantly reduce the interannual variability through natural low-pass filtering. This feature is distinct from the random error represented by reconstruction uncertainty ranges. We admit that our analysis might depend on the choice of the speleothem calcite model and the climate model simulation used to provide the pseudo-proxies. However, our model simulations suggest that the stalagmite $\delta^{18} \mathrm{O}_{\text {calc }}$ is a sensitive recorder on decadal and longer time scales. As a next step, several other locations will be studied and compared to each other in order to study the underlying physics for different regions. Our correlation maps suggest that other Central European caves should show a similar spatiotemporal behaviour at least on decadal to multidecadal timescales. Furthermore, we will extend our approach to multi-centennial timescales by using long-term 
numerical experiments (Herold and Lohmann, 2009; Wei and Lohmann, 2012; Dietrich et al., 2013) in combination with our proxy modules. Such experiments can help to interpret long-term $\delta^{18} \mathrm{O}$ variability in stalagmites.

Acknowledgements. We thank the reviewers Andy Baker and Francesco Pausata for their constructive comments. This work is funded by Helmholtz through the programmes PACES and REKLIM, and by DFG through the research unit DAPHNE.

Edited by: C. Spötl

\section{References}

Baker, A., Wilson, R., Fairchild, I. J., Franke, J., Spötl, Ch., Mattey, D., Trouet, V., and Fuller, L.: High resolution $\delta^{18} \mathrm{O}$ and $\delta^{13} \mathrm{C}$ records from an annually laminated Scottish stalagmite and relationship with last millennium climate, Global Planet. Change, 79, 303-311, doi:10.1016/j.gloplacha.2010.12.007, 2011.

Bjerknes, J.: Atlantic air-sea interaction, Adv. Geophys., 10, 1-82, 1964.

Brachert, T. C., Reuter, M., Felis, T., Kroeger, K. F., Lohmann, G., Micheels, A., and Fassoulas, C.: Late Miocene corals (10 Ma) from Crete (Greece) document interannual climate variability controlled by the Icelandic Low, Earth Planet. Sc. Lett., 245, 8194, doi:10.1016/j.eps1.2006.03.005, 2006.

Cruz, F. W., Vuille, M., Burns, S. J., Wang, X. F., Cheng, H., Werner, M., Edwards, R. L., Karmann, I., Auler, A. S., and Nguyen, H.: Orbitally driven east-west antiphasing of South American precipitation, Nat. Geosci., 2, 210-214, doi:10.1038/Ngeo444, 2009.

Dayem, K. E., Molnar, P., Battisti, D. S., and Roe, G. H.: Lessons learned from oxygen isotopes in modern precipitation applied to interpretation of speleothem records of paleoclimate from eastern Asia, Earth Planet. Sc. Lett., 295, 219-230, 2010.

Deininger, M., Fohlmeister, J., Scholz, D., and Mangini, A.: Isotope disequilibrium effects: The influence of evaporation and ventilation effects on the carbon and oxygen isotope composition of speleothems - A model approach, Geochim. Cosmochim. Acta, 96, 57-79, 2012.

Delworth, T. L. and Mann, M. E.: Observed and simulated multidecadal variability in the Northern Hemisphere, Clim. Dynam., $16,661-676,2000$.

Deser, C. and Blackmon, M.: Surface climate variations over the North Atlantic ocean during winter: 1900-1989, J. Climate, 6, 1743-1753, 1993.

Dietrich, S., Werner, M., Spangehl, T., and Lohmann, G.: Influence of orbital forcing and solar activity on water isotopes in precipitation during the mid and late Holocene, Clim. Past, 9, 13-26, doi:10.5194/cp-9-13-2013, 2013.

Dima, M. and Lohmann, G.: Fundamental and derived modes of climate variability: concept and application to interannual timescales, Tellus A, 56, 229-249, 2004.

Dima, M. and Lohmann, G.: A hemispheric mechanism for the Atlantic Multidecadal Oscillation, J. Climate, 20, 2706-2719, 2007.

Dima, M., Rimbu, N., Stefan, S., and Dima, I.: Quasi-decadal variability in the Atlantic Basin involving tropics-midlatitudes and ocean-atmosphere interactions, J. Climate, 14, 823-832, 2001.
Dreybrodt, W. and Scholz, D.: Climatic dependence of stable carbon and oxygen isotope signals recorded in speleothems: From soil water to speleothem calcite, Geochim. Cosmochim. Acta, 75, 734-752, 2011.

Drysdale, R. N., Hellstrom, J. C., Zanchetta, G., Fallick, A. E., Sánchez Gõni, M. F., Couchoud, I., McDonald, J., Maas, R., Lohmann, G., and Isola, I.: Evidence for obliquity forcing of glacial Termination II, Science, 325, 1527-1531, doi:10.1126/science.1170371, 2009.

Fairchild, I. J. and Treble, P. C.: Trace elements in speleothems as recorders of environmental change, Quaternary Sci. Rev., 28, 449-468, 2009.

Fairchild, I. J., Smith, C. L., Baker, A., Fuller, L., Spötl, C., Mattey, D., and McDermott, F.: Modification a preservation of environmental signals in speleothems, Earth-Sci. Rev., 75, 105-153, 2006.

Felis, T., Lohmann, G., Kuhnert, H., Lorenz, S., Scholz, D., Pätzold, J., Al-Rousan, S. A., and Al-Moghrabi, S. M.: Increased seasonality in Middle East temperatures during the last interglacial period, Nature, 429, 164-168, 2004.

Fohlmeister, J., Schröder-Ritzrau, A., Scholz, D., Spötl, C., Riechelmann, D. F. C., Mudelsee, M., Wackerbarth, A., Gerdes, A., Riechelmann, S., Immenhauser, A., Richter, D. K., and Mangini, A.: Bunker Cave stalagmites: an archive for central European Holocene climate variability, Clim. Past, 8, 1751-1764, doi:10.5194/cp-8-1751-2012, 2012.

Grosfeld, K., Lohmann, G., Rimbu, N., Fraedrich, K., and Lunkeit, F.: Atmospheric multidecadal variations in the North Atlantic realm: proxy data, observations, and atmospheric circulation model studies, Clim. Past, 3, 39-50, doi:10.5194/cp-3-39-2007, 2007.

Herold, M. and Lohmann, G.: Eemian tropical and subtropical African moisture transport: an isotope modelling study, Clim. Dynam., 33, 1075-1088, doi:10.1007/s00382-008-0515-2, 2009.

Hurrell, J. W.: Decadal Trends in the North Atlantic Oscillation: Regional Temperatures and Precipitation, Science, 269, 676-679, 1995.

Justino, F. and Peltier, W. R.: The glacial North Atlantic Oscillation, Geophys. Res. Lett., 32, L21803, doi:10.1029/2005GL023822, 2005.

Kaufmann, G.: Stalagmite growth and palaeo-climate: the numerical perspective, Earth Planet. Sc. Lett., 214, 251-266, 2003.

Keenlyside, N. S., Latif, M., Jungclaus, J., Kornblueh, J. L., and Roeckner, E.: Advancing decadal-scale climate prediction in the North Atlantic sector, Nature, 453, 84-88, doi:10.1038/nature06921, 2008.

Kluge, T., Riechelmann, D. F. C., Wieser, M., Spötl, C., Sültenfuss, J., Schröder-Ritzrau, A., Niggemann, S., and Aeschbach-Hertig, W.: Dating cave drip water by tritium, J. Hydrol., 394, 396-406, 2010.

Kushnir, Y.: Interdecadal variations in North Atlantic sea surface temperature and associated atmospheric conditions, J. Climate, 7, 141-157, 1994.

Lachniet, M. S.: Climatic and environmental controls on speleothem oxygen-isotope values, Quaternary Sci. Rev., 28, 412-432, 2009. 
Langebroek, P. M., Werner, M., and Lohmann, G.: Climate information imprinted in oxygen-isotopic composition of precipitation in Europe, Earth Planet. Sc. Lett., 311, 144-154, doi:10.1016/j.epsl.2011.08.049, 2011.

Latif, M., Arpe, K., and Roeckner, E.: Oceanic control of decadal North Atlantic sea level pressure variability in winter, Geophys. Res. Lett., 27, 727-730, 2000.

LeGrande, A. N. and Schmidt, G. A.: Sources of Holocene variability of oxygen isotopes in paleoclimate archives, Clim. Past, 5, 441-455, doi:10.5194/cp-5-441-2009, 2009.

Lewis, S. C., LeGrande, A. N., Kelley, M., and Schmidt, G. A.: Water vapour source impacts on oxygen isotope variability in tropical precipitation during Heinrich events, Clim. Past, 6, 325-343, doi:10.5194/cp-6-325-2010, 2010.

Li, C. and Battisti, D. S.: Reduced Atlantic storminess during Last Glacial Maximum: Evidence from a coupled climate model, J. Climate, 21, 3561-3579, 2008.

Liu, Z.: Dynamics of Interdecadal Climate Variability: A Historical Perspective, J. Climate, 25, 1963-1995, doi:10.1175/2011JCLI3980.1, 2012.

Lohmann, G. and Schöne, B. R.: Climate signatures on decadal to interdecadal time scales as obtained from mollusk shells (Arctica islandica) from Iceland, Palaeogeogr. Palaeocl. Palaeoecol., doi:10.1016/j.palaeo.2012.08.006, in press, 2013.

Lohmann, G., Rimbu, N., and Dima, M.: Climate signature of solar irradiance variations: Analysis of long-term instrumental and historical data, Int. J. Climatol., 24, 1045-1056, doi:10.1002/joc.1054, 2004.

Majoube, M.: Fractionnement en oxygènè 18 et en deutérium entre l'eau et sa vapeur, Journal de Chimie et Physique, 68, 14231436, 1971.

Mann, M. E., Park, J., and Bradley, R. S.: Global interdecadal and century-scale climate oscillations during the past five centuries, Nature, 378, 266-270, 1995.

McDermott, F.: Palaeo-climate reconstruction from stable isotope variations in speleothems: a review, Quaternary Sci. Rev., 23, 901-918, 2004.

Mignot, J. and Frankignoul, C.: On the variability of the Atlantic meridional overturning circulation, the NAO and the ENSO in the Bergen Climate Model, J. Climate, 18, 2361-2375, 2005.

Mühlinghaus, C., Scholz, D., and Mangini, A.: Modelling stalagmite growth and $\delta^{13} \mathrm{C}$ as a function of drip interval and temperature, Geochim. Cosmochim. Acta, 71, 2780-2790, 2007.

Mühlinghaus, C., Scholz, D., and Mangini, A.: Modelling fractionation of stable isotopes in stalagmites, Geochim. Cosmochim. Acta, 73, 7275-7289, 2009.

Pausata, F. S. R., Li, C., Wettstein, J. J., Nisancioglu, K. H., and Battisti, D. S.: Changes in atmospheric variability in a glacial climate and the impacts on proxy data: a model intercomparison, Clim. Past, 5, 489-502, doi:10.5194/cp-5-489-2009, 2009.

Pausata, F. S. R., Battisti, D. S., Nisancioglu, K. H., and Bitz, C. M.: Chinese stalagmite $\delta^{18} \mathrm{O}$ controlled by changes in the Indian monsoon during a simulated Heinrich event, Nat. Geosci., 4, 474-480, 2011a.

Pausata, F. S. R., Li, C., Wettstein, J. J., Kageyama, M., and Nisancioglu, K. H.: The key role of topography in altering North Atlantic atmospheric circulation during the last glacial period, Clim. Past, 7, 1089-1101, doi:10.5194/cp-7-1089-2011, 2011 b.
Philander, S. G.: El Nino, La Nina, and the Southern Oscillation, Academic Press, New York, 293 pp., 1990.

Rayner, N. A., Horton, E. B., Parker, D. E., Folland, C., and Hackett, R. B.: Version 2.2 of the Global sea-Ice and Sea Surface Temperature data set, 1903-1994, Clim. Res. Tech. Note 74, Hadley Centre, UK Meteorol. Off., Bracknell, England, 1996.

Rayner, N. A., Brohan, P., Parker, D. E., Folland, C. K., Kennedy, J. J., Vanicek, M., Ansell, T., and Tett, S. F. B.: Improved analyses of changes and uncertainties in sea surface temperature measured in situ since the mid-nineteenth century: the HadSST2 data set, J. Climate, 19, 446-469, 2006.

Richards, D. A. and Dorale, J. A.: U-series chronology and environmental applications of speleothems, Int. J. Speleol., 39, 35-46, 2010.

Riechelmann, D. F. C., Schröder-Ritzrau, A., Scholz, D., Fohlmeister, J., Spötl, C., Richter, D. K., and Mangini, A.: Monitoring Bunker Cave (NW Germany): A prerequisite to interpret geochemical proxy data of speleothems from this site, J. Hydrol., 409, 682-695, 2011.

Rimbu, N. and Lohmann, G.: Decadal variability in a central Greenland high-resolution deuterium record and its relationship to the frequency of daily atmospheric circulation patterns from the North Atlantic Region, J. Climate, 23, 4608-4618, doi:10.1175/2010JCLI3556.1, 2010.

Rimbu, N., Lohmann, G., Felis, T., and Pätzold, J.: Arctic Oscillation signature in a Red Sea coral, Geophys. Res. Lett., 28, 29592962, 2001.

Robertson, A. W., Mechoso, C. R., and Kim, Y.-J.: The influence of Atlantic sea surface temperature anomalies on the North Atlantic Oscillation, J. Climate, 13, 122-138, 2000.

Rodwell, M. J., Rowell, D. P., and Folland, C. K.: Oceanic forcing of the wintertime North Atlantic Oscillation and European climate, Nature, 398, 320-323, 1999.

Roeckner, E., Arpe, K., Bengtsson, L., Christoph, M., Claussen, M., Dümenil, L., Esch, M., Giorgetta, M., Schlese, U., and Schulzweida, U.: The atmospheric general circulation model ECHAM4: Model description and simulation of present-day climate, MPI Report 218, Max-Planck-Institute for Meteorology, Hamburg, Germany, 90 pp., 1996.

Scholz, D. and Hoffmann, D. L.: ${ }^{230} \mathrm{Th} / \mathrm{U}$-dating of fossil reef corals and speleothems, Quaternary Sci. J., 57, 52-77, 2008.

Scholz, D., Mühlinghaus, C., and Mangini, A.: Modelling the evolution of $\delta^{13} \mathrm{C}$ and $\delta^{18} \mathrm{O}$ in the solution layer on stalagmite surfaces, Geochim. Cosmochim. Acta, 73, 2592-2602, doi:10.1016/j.gca.2009.02.015, 2009.

Sutton, R. T. and Allen, R. M.: Decadal predictability in North Atlantic sea surface temperature and climate, Nature, 388, 563567, 1997.

Sutton, R. T. and Hodson, D. L. R.: Influence of the ocean on North Atlantic climate variability 1871-1999, J. Climate, 16, 32963313, 2003.

von Storch, H. and Zwiers, F. W.: Statistical Analysis in Climate Research, Cambridge University Press, Cambridge, 484 pp., 1999.

Wackerbarth, A.: Towards a better understanding of climate proxies in stalagmites - modelling processes from surface to cave, Dissertation, Ruprecht-Karls-Universität, Heidelberg, 2012.

Wackerbarth, A., Scholz, D., Fohlmeister, J., and Mangini, A.: Modelling the $\delta^{18} \mathrm{O}$ value of cave drip water and speleothem calcite, Earth Planet. Sc. Lett., 299, 387-397, 2010. 
Wackerbarth, A., Langebroek, P. M., Werner, M., Lohmann, G., Riechelmann, S., Borsato, A., and Mangini, A.: Simulated oxygen isotopes in cave drip water and speleothem calcite in European caves, Clim. Past, 8, 1781-1799, doi:10.5194/cp-8-17812012, 2012.

Walker, G. T.: Correlation in seasonal variations of weather IX, Mem. India Meteor. Dept., 24, 275-332, 1924.

Walker, G. T. and Bliss, E. W.: World weather V, Memoir. Roy. Meteorol. Soc., 4, 53-84, 1932.

Wang, Y. T., Cheng, H., Edwards, R. L., An, Z. S., Wu, J. Y., Shen, C.-C., and Dorale, J. A.: A high-resolution absolute-dated late Pleistocene monsoon record from Hulu Cave, China, Science, 294, 2345-2348, 2001.
Wei, W. and Lohmann, G.: Simulated Atlantic Multidecadal Oscillation during the Holocene, J. Climate, 25, 6989-7002, doi:10.1175/JCLI-D-11-00667.1, 2012.

Werner, M. and Heimann, M.: Modeling interannual variability of water isotopes in Greenland and Antarctica, J. Geophys. Res.Atmos., 107, 4001, doi:10.1029/2001JD900253, 2002.

Yuan, D., Cheng, H., Edwards, R. L., Dykoski, C. A., Kelly, M. J., Zhang, M., Qing, J., Lin, Y., Wang, Y., Wu, J., Dorale, J. A., An, Z., and Cai, Y.: Timing, Duration, and Transitions of the Last Interglacial Asian Monsoon, Science, 304, 575-578, doi:10.1126/science.1091220, 2004. 